\title{
Puncture your Papañca
}

\author{
Ajahn Amaro ${ }^{1}$ \\ Accepted: 31 August 2021 / Published online: 4 November 2021 \\ (c) Amaravati Publications 2021
}

In the teachings the Buddha describes what in Pali is referred to as papañca, or "conceptual proliferation" in English. This is a theme it's useful to explore and clarify, because it helps us to understand our thinking and how not to get lost in the realm of our mental creations.

One particular sutta spells this process out very clearly in detail, Sutta 18 of the Middle Length Discourses, the Madhupindika Sutta. "Madhupindika" literally means "the sweet morsel" or "the ball of honey", because it is such a delectable teaching that upon hearing it, Venerable Ānanda was prompted to say, "This is amazing, this is wonderful. This is the most gorgeous, this is the most delectable, the most fantastic, delightful teaching. It is like a sweet ball of honey. What should we call this sutta, Venerable Sir?".

The Buddha answered, "You can call it the Honey Ball Discourse, Ānanda." And that is what it has been called ever since.

This sutta explains how things start off with a simple sense perception - the eye views a form, the ear hears a sound, the nose smells an odor, the tongue tastes a flavor, the body perceives a tactile object, or the mind perceives a thought or an emotion. For example, take the eye seeing a form: there is the eye, the physical form seen and the eye-consciousness which arises. Those three things coming together are phassa or sense-contact. This happens very quickly. The neural impulse shoots down the optic nerve, reaches the visual cortex in the brain and you get a feeling, liking, disliking or a neutral feeling; and this feeling happens even before there is cognition. The Buddha pointed out that this primary impact of any sense awareness is already divided into "like", "dislike" or a neutral response — dangerous, desirable or don't worry about it. This is a very primal mode of finding our way in our environment. It is basic sensory activity.

Ajahn Amaro

ajahn.amaro@gmail.com

1 Amaravati Buddhist Monastery, Great Gaddesden, Hemel Hempstead, Hertfordshire HP1 3BZ, UK
In this way sense-contact, phassa, leads to feeling: pleasant feeling, painful feeling or neutral feeling. Following

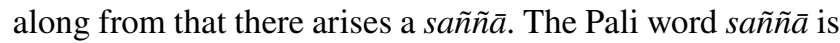
usually translated as "perception". It is related to the English word "sign" - they are connected in terms of their meaning and their origins.

The sañ $\tilde{a} \bar{a}$ is the designation of a particular sense contact. So again with regard to the eye and visual form, after the initial impact in the visual cortex, the sañ $\tilde{a} \bar{a}$ would be the registering of red or green or sharp-edged or blurry; the forming of the basic perception before any kind of naming, the primary definition or ordering of what is being perceived.

Then rapidly following sañña $\bar{a}$ is vitakka. Vitakka means "to think". This is where the naming happens - the eye sees a color and it recognizes black, green, orange, etc. It is the simple naming of an object. So far, so good. This is all very uncomplicated.

Up to this stage, the whole process of experience is not really giving rise to much dukkha, insecurity or dissatisfaction of any kind. It is also happening very quickly.

The trouble begins when vitakka leads to papañca, when thought leads to associative thinking, memories of like or dislike, or opinions. At the level of sañña and vitakka, perception and naming, life stays very simple - it's just feeling, perception and the simple naming of an object: "In the heard there is only the heard, in the seen there is only the seen..." When the mind can stay at that simple level of categorization and apprehending, the receiving of sense objects, everything is fine and dandy, it is all very simple and clear. But as we know, things don't usually stop at that naming point. What comes next are the strings of association. This is papañca. And this is the way our minds work - we are prone to thinking, remembering, conceptual proliferation, prolixity, the mind setting off and running with ideas and thoughts and projections.

There is a wonderful book called Why Zebras Don't Get Ulcers by the scientist Robert Sapolsky, who spends his time partly at Stanford University in California and partly living among troops of baboons in Kenya. He has spent a lot of time with baboons in the last few decades. Much of his 
book is about baboon life and politics, and he gives all his baboons wonderful biblical names - Rebecca and Obadiah, Ebenezer and Hepzibah.

The thesis of Why Zebras Don't Get Ulcers is that if you are a zebra, you are on the menu for the average lion out on the savannah. When you see a lion coming towards you, you need stress and you need to get stressed fast. You want your heart to start beating rapidly, you want that adrenalin to go pumping, you need to get lots of energy to your legs and you want to start running. And you want maximum stress as the lion starts to chase after you. You need to get your system cranked up as much as you possibly can in that stressed situation. You need to have your anxiety levels very, very high. You need to become afraid, because fear is what is going to save you. The zebras who are nonchalant about lions are the ones who end up as breakfast. The ones who have high levels of anxiety survive.

So zebras need to be afraid. They need to move quickly. They can shut off their digestive and reproductive functions, get as much sugar into the system as possible, get the heart beating rapidly and pump the whole system with adrenalin, so they can move as quickly as possible. And within a couple of minutes one of two results will have happened: either they will have got away or they will have been caught and killed. So they only need to stay stressed for a couple of minutes, and if they get away they don't need to keep the stress reaction going, because the lion has given up and gone after somebody else - somebody else is currently being turned into breakfast and so the worries of Zebra \#1 are over. There is no need to sustain the stress reaction because the worst has just happened to someone else. There is no need to be afraid any more, so the stress switches off.

Sometimes on television wildlife documentaries you will see an animal, such as a zebra, get caught by lions. Its guts are ripped open and the lions are chewing on it. Meanwhile three or four other zebras are happily grazing nearby, just casually glancing over: "Oh, look - there's cousin George being eaten." It's quite disturbing, isn't it? You think, "Don't they care? How can they be so callous?" But it's because they know that if cousin George is being eaten, they are not being eaten, so they don't worry about it. And because they apparently can't project into the future, they never think, "Tomorrow that could be me." They don't make a problem out of it. Hence zebras don't get ulcers.

As human beings, however, we have the capacity to reflect: "Ooh - George got it yesterday, and if you do the statistics, how much longer is it going to be until I'm on the menu?" We human beings can remember the past and we can imagine a future, so we don't get that stress reaction going for just two minutes - we can keep it going for a couple of months or years, so we get ulcers. The stress reaction is sustained through our papañca, through our conceptual thought and our capacity to remember and imagine.
Memory and thought are useful things, and the imagination and the ability to project into the future have their purpose, but when these abilities overspill their boundaries and we start incessantly imagining, or we can't let go of painful things that have happened in the past, or stop anticipating painful or difficult things that might happen in the future, we create ongoing anxiety. Humans maintain the stress reaction hour after hour, day after day, week after week. We make ourselves ill with anxiety, restlessness, rage, rapacity and depression, the different ailments which beset society.

So if you want to avoid ulcers you need to work on papañca. Papañca is the habit of buying into our thoughts, believing in them and creating images of past and future, and going off and inhabiting them - building castles in the air and going to live there. That is what causes us so much distress.

This conceptual proliferation, papañca, is actually not the end of the whole sequence described in the sutta. The last part of the sequence is what's called papañca-sanñasankha - "the multiplicity of thoughts and perceptions that the mind produces and which beset the heart". That is a brief translation. Papañca-sañ̃a-sankhā is the whole array of thoughts and perceptions which are prone to prolixity. So by the time you get to the end of the process and have reached papañca-sanñā-sankhā, there is "me here and the world out there", and the state of tension between the two either tension with something I want which I haven't got, or something I' $m$ afraid is going to get me and want to get away from. There is a duality. And that subject-object duality is rigidly fixed into place, "me here" and "the world out there", and there is the state of tension and dukkha arising from that.

This whole process, from the beginning with the simple perception through to the end with "me here" and "the world out there", happens very quickly. So learning to track this process and seeing how it begins requires the development of mindfulness and wisdom. The mind has to be trained not to follow the habitual pathways of papañca.

When you see the mind has wandered off into some kind of conceptual labyrinth, into trains of thought and association, take the trouble to follow it back. This is the practice of following the string of thoughts and associations back to its origin. It might not seem a terribly fruitful exercise, but in my experience it is very revealing. Over and over again we realize that the mind gets caught up in excitements or fantasies, fears and anxieties, or gets lost in rewriting the past, and that all this is completely void of substance.

I used to be very fond of rewriting how things might have been in the past. I spent an amazing amount of time in my early monastic life re-scripting how things could or should have been. Often it would be fifteen or twenty minutes before the wisdom factor would wade in and say, "But it didn't actually happen that way. That didn't happen, it wasn't that way, so there is no need to get upset, there is no need to 
get excited, no need to get worried. It didn't happen, and it was ten years ago that it didn't happen!" But our mind does that, doesn't it?

We also go back and revisit mistakes we made, glorious moments, or things which were memorable or painful we re-inhabit them and bring them to life. Whenever we are aware that the mind is caught up in a proliferation, we need to take the trouble to catch that process like netting a butterfly. Catch that thought. Actually, a butterfly is a very appropriate symbol, since the Greek word "psyche" means not just "the mind" but "butterfly". So a psychologist is someone who studies this very butterfly nature.

So we catch that particular fluttering piece of papañca, and then we follow the sequence of thoughts and associations back to where they came from. Every time we will notice that it was started by just a random thought that popped into the mind - there was a smell from the kitchen which triggered the memory of a particular food, or the sight of somebody's shawl triggered the memory of Aunt Matilda's dress. Following it back, we realize that it was just a smell, just a sound, just a random memory. That is all. When we get to the source, the origin, it is utterly unburdensome, uncomplicated.

The string of papañca-sanña-sankhā leads to "me here" and "the world out there", and there is a solidly, definitely divided experience. The further you trace it back to the source, the less there is a sense of a "me here" and "the world out there". There is just hearing, seeing, smelling, tasting, touching. "In the heard there is only the heard", in the hearing there is only the hearing. The same with seeing, smelling, tasting, touching. There is no sense of self embedded within that. It is just the world as it is experienced.

There is a great master of the Korean Buddhist tradition called Chinul who developed this method. The English translation of the Korean term he used for it is "tracing back the radiance". There is a book of Chinul's teachings, translated by Robert Buswell, which bears this title. The book is a very helpful guide to using the quality of mindfulness and careful attention to unpick the tangles of papañca, and to keep bringing the mind back to the simplicity of knowing, feeling, hearing, smelling, tasting, touching, cognizing, and then acknowledging how the world feels. What is the experience of the world when it is simply this way, when the heart is simply open to sense perception?

When we do this, when this is carried through, there is a wonderful simplicity, an easefulness and a sense of integration. So I would really encourage this straightforward exercise. It also reveals the tracks down which the mind moves. You can become familiar with your own mental habits: whether you are a greed type or an aversion type, or whether you are a really good complainer. You realize how even a pleasant feeling or a pleasant sound can lead to criticizing, complaining or grumbling if you are that type.
Or if you are a greed type, even a painful feeling can lead to something you are fantasizing about acquiring. So this simple process can help us get to know the patterns in which our mind moves, the patterns of conditioning; and by becoming familiar with those patterns we can free the heart from them.

We tend to think, "I am in here, the world is out there, and I am perceiving the world." But I find it extremely helpful to keep recognizing that we don't experience the world we experience our mind's representation of the world. This is something that the Buddha pointed to (e.g., at S 2.26, S 35.116): "That in the world by which one is a perceiver of the world, a conceiver of the world - this is called "the world" in the Noble One's discipline. And what is it in the world though which one does that? It is with the eye, the ear, the nose, the tongue, the body and the mind." That is "the world" in terms of the Buddha's teaching. Obviously we can talk about this planet as being the world, or the stars and galaxies and space being the world. In some ways that usage of the term is fair enough. It is reasonable. But it is important to recognize that when we are trying to live in a reflective way, develop the qualities of wisdom and understanding and free the heart, the most helpful way of understanding the world is just exactly as I have been describing - the world is sights, sounds, smells, taste, touch, thought. That is the world because that is the world as we know it.

I'm not saying that the whole world is an illusion conjured up by us as individuals. There is a substrate. There is a basis on which our perceptions are formed. But what we know about the world is constructed from the information that our senses weave together. That is the coordinating capacity of the mind. The mind is the sixth sense which draws the first five senses together and coordinates them. The world the mind creates is the world that we know. The world is put together by our minds. These perceptions are all we can know. All we have ever known has been through the agency of this mind.

This shouldn't be seen as a limitation. But we should recognize that this is the programme, this the world we live in and the world from which we learn. And that world is formed, colored and shaped by the language we have learned and the experiences that we have had.

I feel that Robert Sapolsky's Why Zebras Don't Get Ulcers should be required reading. Another book that is almost as good is called Don't Sleep, There are Snakes by Daniel Everett. This book was written by a former Christian missionary who went out to the Amazon jungle on a mission to convert a particular tribe to Christianity, but ended up being converted himself. It is an interesting tale because the language of this particular tribe, the Pirahã, doesn't seem to be connected to anybody else's language in the world. They have a completely different way of symbolizing reality. I won't bore you with the details, because I know that listening to other people talk about books about which they're 
enthusiastic can be extremely trying. But here are a few small snippets just to give you a taste.

The Pirahã have no concept of number. Many tribal peoples around the world have a very simple idea about numbers, like 'One, two, three, lots'; or basic numbers, or numbers up to ten. The Pirahã have no concept of number at all. They can't think the thought of one or two or three. So you may have believed that mathematics was a sort of basis of life in the universe; you may have thought that everything was organized through ones, twos, threes, fours, fives and sixes and so on. But the Pirahã do not do numbers. Number has no meaning for them.

There's an interesting little incident in the book. The Pirahã are a very intelligent people and live in communication with other tribes. One day the tribespeople approached the missionary and said, "Now, you've been talking about this number stuff. We're really interested because we think that these guys up the river are ripping us off. We know they are not being fair, and we think this number stuff you are talking about might help us figure out how they are not being fair. So can you teach us? We'll put some effort into this. We'll really give it a go." For eight months the missionary took the six brightest people in the village and tried to talk them through what a number was - one stick, and then there are two sticks, three sticks, etc. After eight months of working together with the half dozen brightest people in the village, not a single one of them could count up to ten. It just had no meaning.

They also can't talk about things that haven't been seen by either themselves or an eye-witness. So when the missionary tried to explain the battle of Jericho and how the walls came tumbling down, they said, "That must have been a big sound. That must have been really noisy. What did it look like?"

"I wasn't there. That was a long time ago."

"So you didn't see it? Who told you about it?"

"I read about it in a book. Nobody told me about it. It

happened thousands of years ago."

"So you didn't see it and you don't know anybody who saw it?"

"No. It's a story."

As soon as it was clear that he had not been an eyewitness, it wasn't as though they said, "Well, that's boring" or, "We don't believe you"; they would simply disconnect. The words would stop having meaning if they didn't relate to something that was personally witnessed. If someone walks down a path and goes round the corner, they can't talk about them because they are not around.

They don't have words for individual colors, so they compare things to natural qualities. Black is known as "old blood". They have no way of saying green, which in the Amazon is rather unusual. And they have no language for time.
Interestingly, they are an extremely cohesive society. They are not all saints, they have their problems, but they are an extraordinarily well-integrated society. And their language is extremely complex, so it took the missionary fifteen or twenty years to really master it, even though it doesn't have things like numbers, colors or time. They have a huge range of different verb forms to describe experiences. So he actually had to become like them, to think like them, in order to learn the language, because it was so different. And through thinking like them his relationship to biblical Christianity fell to pieces.

So realizing how differently some people can see the world, free from our familiar constructs, helps put our own fabrications and preoccupations into perspective. We create a world where numbers are real. Numbers have names, you can add them and subtract them, and it all seems normal and absolutely unremarkable. We create a world where things have colors - this is black, that is brown - but these are constructed realities, fabricated perceptions. They don't have any intrinsic existence. "Number" is something our mind creates. It doesn't have an intrinsic existence of its own. "Personhood," "individuality" and "time" are constructed. The Pirahã tribe have no real way of talking about the past or the future. But in the West we create concepts of time and then make them real by our communal belief in them. We say, "Today is Friday and it is nine-forty." If everyone in our office agrees to arrive at work at "ten o' clock", we are oblivious to the notion that "ten o'clock" is a Western construction on which everyone has colluded.

Our name is a construct, as is our notion of individuality. We construct these things and live with them for useful reasons. But the more we take them to be absolute truths, then the more we are stuck in sillabbata parāmāsa, attachment to conventions. So next time you look at a clock and recognize that it is seven-thirty, maybe ask yourself what that would mean to a member of the Pirahã tribe. What is seven?

A friend in California, a computer scientist, had a daughter who was a brilliant artist but almost completely dis-numerate - numbers meant almost nothing to her. She struggled with mathematics at school. At one point it seemed as if she was improving, but at the age of nine she asked her father, "Is four less than seven, or is it bigger?" Like the Pirahã she hadn't quite got this number thing figured out. She was an extraordinarily gifted graphic artist, but numbers meant nothing to her.

So we must learn to be able to reflect on the fact that this world is a created world, a compounded world. Learning to see this helps us to be lokavidu, to know the world. If we believe that our world is absolutely real, rather than that this is just our own particular version of it, constructed, compounded and dependent, we are always going to be tied to the world and limited by it. 
In another very significant sutta (S 2.26) there is a dialogue between the Buddha and a devata called Rohitassa. This is a teaching of which Bhikkhu Bodhi, who is one of the great translators of the Pali Canon into English, says it "... may well be the most profound proposition in the history of human thought." The devata Rohitassa encounters the Buddha and says to him, "When I was a human being in my last life I was a yogi and I had the ability to walk through the sky, I was a skywalker. I could walk from one side of India to the other in no great time. I made a vow that I would walk until I reached the end of the world. But even though I walked through the sky non-stop for many years, still I couldn't reach the end of the world, and I died on my journey before I had reached the world's end." And the Buddha said, "Yes, Rohitassa, that is how it is - you cannot reach the end of the world by walking. But I tell you this: if you don't reach the end of the world you won't reach the end of suffering."

That's a compelling statement. You can't reach the end of the world by walking, but if you don't reach the end of the world you won't reach the end of suffering. This might sound like a bit of a disappointment, but then the Buddha said, "The world, Rohitassa, is in this very fathom-long body with its thoughts and perceptions - in this body there is the world, there is the origin of the world, there is the cessation of the world, and the way leading to the cessation of the world." So in this very life, within the sphere of this living experience, the world can be known.

When we recognize that the world is created through our thoughts and perceptions, that we build this world, that it is a caused, dependent thing, we can also see that it arises and therefore ceases. It is a process that is known through our awareness, and it is in this awareness that "the world ends".

You will notice that the formulation the Buddha expresses here is very close to the formulation of the Four Noble Truths. Seeing the world as a solid, separate thing equates with dukkha - insofar as we make the world solid and separate, there is unsatisfactoriness, suffering. When that is understood, when the world is known in that way, when that whole process of arising and ceasing of perception is seen the world takes shape, arises, forms and then dissolves - this equates to understanding the cause of dukkha. We see dukkha being caused, we see $d u k k h a$ arising, we see $d u k k h a$ ceasing. Through this the heart is liberated from all dukkha. In the same way, once the world is known for what it is, once we have seen the comings and goings of the world - the world is caused, the world arises, the world ceases - the heart is able to be freed from identification with the world, the heart is liberated from the world.

In a similar vein, there is another very significant sutta from the Dīgha Nikāya, the Kevaddha Sutta (D 11). In this discourse, the Buddha is teaching a layman named Kevaddha who has asked him some questions. The Buddha tells him the story of a monk who had developed some skill in meditation, but during the course of his meditation a question arose in his mind:

"Where is it that earth, water, fire and wind fade out without remainder?" One could also rephrase the question: "Is there a place where the world and the things of the world - earth, water, fire and wind - will fade away and not arise again? Where might I find that the end of the world?"

The Buddha tells Kevaddha how this question arose in the mind of that meditator, and how he was eager to pursue it, so he absorbed his mind in concentration and the pathway to the different heavenly realms appeared in front of him. First he makes his way to the Heaven of the Four Great Kings, the four guardian deities of the world, and says to them, "I've got a question which I've been puzzling over. Can you tell me where it is that the four great elements - earth, water, fire and wind - fade out and cease without remainder?".

The deities reply, "We're the guardian deities. Our job is to look after the world. We're in charge of earth, water, fire and wind, but that kind of question is well beyond us. You should try upstairs. Go to the Tāvatimsa Heaven. Lord Indra is up there and there must be someone, either Lord Indra himself or some other deities in his retinue, who will be able to help you out. This is way too profound for us. We're just the bodyguards here, the bouncers who keep the troublemakers out of the world. We're just the security here, the lokapālas — just the muscle, not philosophers. You'd better try upstairs. They are more skilled in this kind of thing than we are."

So the monk makes his way up to the Tāvatimsa Heaven, the Heaven of the Thirty-Three Deities. He asks his question of the retinue of Indra and they don't know the answer. He then asks Indra himself, who says, "Oh, you know, I'm the King of the Heaven of the Thirty-Three Deities, but that philosophy is beyond me. I can fight wars with the asuras, and I enjoy a good relationship with the Buddha and I like to receive teachings, but this wisdom stuff is really beyond me; you had better try upstairs."

The monk journeyed up one realm after another through the Yāmā Devas to the Tusitā Heaven, to the heaven of those who delight in the creations of others, and all the way up through the seven sensory heavens into the Brahmā world and finally into the realm of Mahā-Brahmā. At each level the deities tell him they don't know the answer and send him upstairs. Finally, he thinks to himself, "Okay, I'm now in the Brahmāloka, so I really ought to be able to get some answers here."

He meets some of the Brahmā gods.

"Oh, Great Beings, you are marvelously glorious, wonderful and beautiful. I am in awe of being in the pres- 
ence of such bright, brilliant, vast and wise deities as yourselves. I have this question: Where is it that earth, water, fire and wind cease without remainder? Where is it that the world comes to an end?"

And they say "Well, you've probably come to the right place, but we can't really help you, because this is the kind of question that only Mahā-Brahmā would be able to answer — we're just his ministers. We're the office staff here. You'll need to wait until Mahā-Brahmā manifests. But if you wait a while, maybe Mahā-Brahmā will actually appear. We never know when the Great One will manifest, but if you wait a bit it could be that the Holy One will appear and then he'll be able to answer your question."

So as you would expect, the monk waited around for a little while, and then a light started to glow in the distance, and Mahā-Brahmā manifested.

The monk approached Mahā-Brahmā and said, "Oh, Mahā-Brahmā, Thrice Great and Wise One, I have a question I wish to ask you which has arisen in my meditation. I wish to know where is it that earth, water, fire and wind fade out and cease without remainder." Mahā-Brahmā said, "I am Brahmā, the Great Brahmā, the Almighty, the Unconquered, the All-Seeing, All-Powerful, the Lord, the Maker and Creator, the Ruler, Appointer and Orderer, Father of All That Have Been and Shall Be."

\footnotetext{
"Well, yes, thank you very much... I understand that you are the Great Mahā-Brahmā and so forth, but I didn't ask about that. I asked where it is that earth, water, fire and wind fade out and cease without remainder."

"I am Brahmā, the Great Brahmā, the Almighty, the Unconquered, the All-Seeing, All-Powerful, the Lord, the Maker and Creator, the Ruler, Appointer and Orderer, Father of All That Have Been and Shall Be."

"Thank you very much again, but that's not actually what I asked."
}

Of course, this being a Buddhist story, they go back and forth three times. It says in the sutta that after the monk posed his question for the third time, Mahā-Brahmā took him by the elbow, led him outside and said, "Look, you are embarrassing me in front of my retinue. I don't know where earth, water, fire and wind fade out and cease without remainder, and you have done wrong in coming all this way up the Brahmā world to ask me. You are a disciple of the Buddha, you are a bhikkhu, so you should rather go and ask the Master because this is his territory and he is the one who can explain to you how to understand this."

Duly chastened, the monk shot down from the Brahmā world, returned to the monastery, found the Buddha and recounted the story. The Buddha said, "Like a land-seeking bird that flies from the ship and goes north, south, east and west, and eventually has to come back to the ship because it hasn't found land, you have eventually come back to me where you should have come in the first place. However, the question you have been asking has been phrased in the wrong way. This is one reason why you were not getting an answer. You shouldn't have asked where earth, water, fire and wind cease without remainder, but rather you should have asked: 'Where is it that earth, water, fire and wind can find no footing?'."

He went on to explain: "The answer is the consciousness (viñ̃̃anam ) which is non-manifest, invisible, formless (anidassanam), limitless, infinite (anantam), and radiant in all directions (sabbato pabham)." These adjectives describe the pure heart, the enlightened mind. "It is here in this awakened consciousness that earth, water, fire and wind can find no footing, they get no traction. Here also, long and short, and coarse and fine, pure and impure can find no footing, there is no landing-place for them in this consciousness.

"In this consciousness, name-and-form, all things material and mental, cease without remainder. Here they are held in check; they are understood and known without delusion."

In this sutta the Buddha uses the Pali term viññana to describe this awakened form of consciousness. This is a very unusual deployment of the term viññana, because it usually means a discriminative consciousness, the mental faculty which distinguishes "this" from "that". In this sutta it means instead an all-encompassing awareness. This one term here becomes shorthand for all the Seven Factors of Enlightenment, a description of the enlightened mind. In addition, the list of adjectives the Buddha uses in the sutta describes this consciousness in more detail. The enlightened mind is awake, it is aware. It is invisible. It is non-manifest. It has no form, it is formless. Viñ̃̃ana is infinitely commodious it has limitless capacity; it is unconfined in its capacity to accommodate all things. This viññana is luminous, radiant in all directions and, in some renditions, this adjective is translated as "accessible on all sides". Either way the terminology works well.

This is the description of the pure heart. It isn't just something from a 2500-year-old story; this is your pure heart, this is your mind.

When there is freedom from obscurations in the heart, when the hindrances have been dropped and there is full wakefulness and attention to the present reality, this is what is experienced: awareness, spaciousness, all-encompassing capacity, brightness, luminosity, radiance. When the heart is in tune with Dhamma, in tune with its own nature, this is how it appears - these are the natural qualities of the pure heart, of the enlightened mind: knowing, emptiness, spaciousness and brightness. These are its natural attributes.

In the Thai language, there is a similar string of terms which Ajahn Chah, Ajahn Buddhadasa and others would use (they alliterate very neatly): sawang (สวาง) means 
"radiant", sa-aht (สะอาด) means "pure", sangoup (สงบ) is "peaceful". Purity, radiance and peace. Ajahn Chah would often say that these are the characteristics of the Dhamma. When the Dhamma is realized, when it is awakened to, when the heart knows the Dhamma, the attributes experienced at that moment are purity, radiance and peacefulness.

Now, you may hear this description of the awakened heart and question its desirability. No footing is found for the long and short, the pure and impure, the coarse and fine - it might sound like a Teflon heart, a non-stick heart. Whatever happens, whether painful or pleasant, beautiful or ugly, coarse or fine, pure or impure; whatever shape earth, water, fire or wind takes there, it has that non-stick quality, no footing can be found. There is nothing; nothing snags, nothing sticks. You may think this description of the awakened heart isn't very appealing because we like to keep sticking to certain things. But in ground-free non-abiding there is a wonderful open freeness to the flow of perception.

These are just some images to bear in mind. When the heart is free from conceptual proliferation it abides in the quality of nippapañca. One of the epithets of the Buddha is Nippapañca, "one who is free from complications". When you read the suttas and study the Buddha's expositions you might think, "His mind is so complicated. Look at this extraordinary range of intricate analyses of the mind and the world, and this fantastic array of images and similes, and his incredible knowledge..." But it is important to realize that the mind of the Buddha was nippapañca, free from complications. Though the enlightened mind, the awakened mind of the Buddha had extraordinary intelligence and capacity for knowledge and information, his mind was still nippapañca. The Buddha's own experience of the present moment was nippapañca, free from all complication.

The saying, "Don't complicate the uncomplicated" (A 4.173 ) is worth bearing in mind. Reality itself, Dhamma itself, is supremely uncomplicated. Do the best you can to refrain from complicating it. The mind has a habit of always wanting to dress things up, to elaborate and explain; these are its habitual complicating tendencies, papañca. Learn to recognize the stress of that, the tension of that $d u k k h a$ of complication. And learn to recognize that we don't have to do that. Just let go. Right here in this moment the heart is free from it and there is an openness to the present. As Ajahn Sumedho says, "Ignorance complicates everything."

When there is avijjā we don't see clearly, there is complication. When there is knowing, there is no complication.

Excerpted from The Breakthrough by Ajahn Amaro, Amaravati Publications, 2016.

Publisher's note Springer Nature remains neutral with regard to jurisdictional claims in published maps and institutional affiliations. 